OPEN ACCESS

Edited by:

Michael Harrison Hsieh,

Children's National Health System,

United States

Reviewed by:

Prashant Khare,

University of Texas Southwestern Medical Center, United States

Kai Matuschewski,

Humboldt University of

Berlin, Germany

*Correspondence:

Zhimin Wang

wangzhimin1975@hotmail.com

Yaohe Wang

yaohe.wang@qmal.ac.uk

Specialty section:

This article was submitted to

Microbial Immunology,

a section of the journal

Frontiers in Immunology

Received: 01 March 2019 Accepted: 16 September 2019

Published: 01 October 2019

Citation:

Miao J, Chard LS, Wang $Z$ and Wang $Y$ (2019) Syrian Hamster as an

Animal Model for the Study on Infectious Diseases.

Front. Immunol. 10:2329.

doi: 10.3389/fimmu.2019.02329

\section{Syrian Hamster as an Animal Model for the Study on Infectious Diseases}

\author{
Jinxin Miao ${ }^{1,2}$, Louisa S. Chard ${ }^{3}$, Zhimin Wang ${ }^{2 *}$ and Yaohe Wang ${ }^{2,3 *}$ \\ ${ }^{1}$ Department of Science and Technology, Henan University of Chinese Medicine, Zhengzhou, China, ${ }^{2}$ Sino-British Research \\ Center for Molecular Oncology, National Center for the International Research in Cell and Gene Therapy, School of Basic \\ Sciences, Academy of Medical Sciences, Zhengzhou University, Zhengzhou, China, ${ }^{3}$ Centre for Molecular Oncology, Barts \\ Cancer Institute, Queen Mary University of London, London, United Kingdom
}

Infectious diseases still remain one of the biggest challenges for human health. In order to gain a better understanding of the pathogenesis of infectious diseases and develop effective diagnostic tools, therapeutic agents, and preventive vaccines, a suitable animal model which can represent the characteristics of infectious is required. The Syrian hamster immune responses to infectious pathogens are similar to humans and as such, this model is advantageous for studying pathogenesis of infection including post-bacterial, viral and parasitic pathogens, along with assessing the efficacy and interactions of medications and vaccines for those pathogens. This review summarizes the current status of Syrian hamster models and their use for understanding the underlying mechanisms of pathogen infection, in addition to their use as a drug discovery platform and provides a strong rationale for the selection of Syrian hamster as animal models in biomedical research. The challenges of using Syrian hamster as an alternative animal model for the research of infectious diseases are also addressed.

Keywords: infectious diseases, Syrian hamster, drug discovery, infection mechanism, biomedical research

\section{INTRODUCTION}

According to data released by the World Health Organization (WHO), infectious agents causing lower respiratory infections, diarrheal diseases, and tuberculosis were ranked in the top ten causes of death worldwide, resulting in 5.7 million deaths in 2016 (1). It is clear that we need to improve our understanding of these diseases and pathogenic agents in order to develop more effective drugs and vaccines. To this end, we need a suitable animal model that can most accurately mimic the pathogenesis of infection as infection usually induces a complex process of host immune responses that in vitro experiments are unable to simulate. Only in vivo models can accurately assess the complexity of host responses and allow the efficacy and adverse effects of drugs or vaccine to be evaluated.

The Syrian hamster (Mesocricetus auratus) has been used as an animal model to study humanassociated diseases for over 60 years. A number of studies have documented that Syrian hamsters represent better models for analysis of viral infections compared to murine models as the similarity to humans with regard to disease symptoms, pathognesis and immune responses is greater (2-4). It has been demonstrated by us and others that human cytokines, including granulocyte-macrophage colony-stimulating factor (GM-CSF) and interleukin-12 (IL-12), are fully functional in hamster models, but not in mouse models $(5,6)$. Together with other advantages, such as fast reproductive rate and ease of handling, Syrian hamsters are a superior choice compared with other small animals. 
Although Syrian hamsters have historically been used in diseases research, their value as an animal model in the study of infectious diseases has only recently been realized. With advancements in gene editing technologies, their popularity has increased significantly (Figure 1). The use of genetically engineered Syrian hamster (GESH) models is critical for understanding disease progression and for developing prophylactic and therapeutic treatment regimens. The first STAT2 gene knockout (KO) Syrian hamster was developed in 2014, using the CRISPR/Cas9 system to target the hamster germline (7). STAT2 is a crucial element of the type I interferon (IFN) signal transduction pathway and the hamster model has emerged as the only small animal model permissive for Adenovirus (AdV) infection, thus, the STAT2 KO model has been critical for the characterization of Adenovirus pathogenesis (8).

\section{SYRIAN HAMSTER USED FOR RESEARCH IN VIRAL INFECTIONS}

The Syrian hamster is an ideal small animal model to study the disease caused by virus infection. Previous studies have shown that some human-specific viruses can also infect, replicate and cause similar pathological alterations in Syrian hamsters (9). In particular, Syrian hamsters are recognized as valuable model for studying emerging and acute human viral diseases caused by highly pathogenic RNA viruses (10). Thus, these animals are of great value for testing potential vaccines and new therapeutic drugs for human use. At present, over 70 different viruses have been investigated using Syrian hamster, and more viral infection studies will be explored in the future (Table 1). In this review, we focus on six viruses for which the use of the Syrian hamster has provided valuable insight into disease pathogenesis.

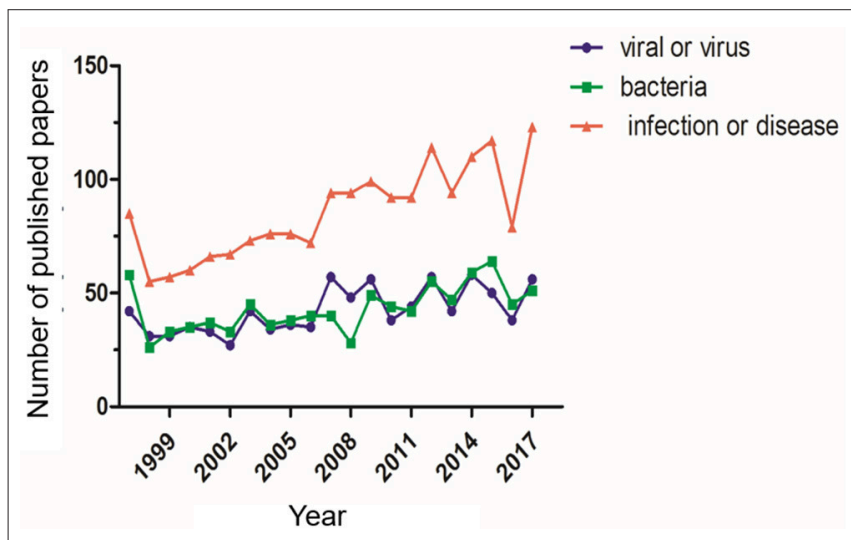

FIGURE 1 | Number of publications using Syrian hamsters as a disease model. The number of publications using Syrian hamsters as an animal model from 1997 through 2017 is shown. For each standard, the number of publications was determined via a search using the ScienceDirect database. The search was performed with the keywords "Syrian hamster" or "golden hamster" AND "model" AND (1) "viral" or "virus," (2) "bacteria," (3) "infection" or "disease".
TABLE 1 | Viral infections in Syrian hamster models.

\begin{tabular}{|c|c|c|c|}
\hline Agent & $\begin{array}{l}\text { Syrian } \\
\text { hamster } \\
\text { strain }\end{array}$ & Disease model & References \\
\hline \multicolumn{4}{|l|}{ Paramyxoviruses } \\
\hline Nipah virus & WT & Nipah disease & (11) \\
\hline Hendra virus & WT & Hendra disease & $(12)$ \\
\hline \multicolumn{4}{|l|}{ Flaviviruses } \\
\hline West Nile virus & WT & $\begin{array}{l}\text { West Nile neurological } \\
\text { syndrome }\end{array}$ & (13) \\
\hline Yellow fever virus* & WT & Yellow fever & (14) \\
\hline Zika virus & STAT2 $^{-/-}$ & Zika virus disease & (15) \\
\hline St. Louis encephalitis virus & WT & $\begin{array}{l}\text { Chronic St. Louis } \\
\text { encephalitis }^{\star \star}\end{array}$ & $(16)$ \\
\hline $\begin{array}{l}\text { Japanese encephalitis } \\
\text { virus }\end{array}$ & WT & Japanese encephalitis & $(17)$ \\
\hline $\begin{array}{l}\text { Eastern equine } \\
\text { encephalitis virus }\end{array}$ & WT & $\begin{array}{l}\text { Eastern equine } \\
\text { encephalitis }\end{array}$ & $(18)$ \\
\hline $\begin{array}{l}\text { Venezuelan equine } \\
\text { encephalitis virus }\end{array}$ & WT & $\begin{array}{l}\text { Venezuelan equine } \\
\text { encephalitis }^{\star \star}\end{array}$ & (19) \\
\hline $\begin{array}{l}\text { Western equine } \\
\text { encephalitis virus }\end{array}$ & WT & $\begin{array}{l}\text { Western equine } \\
\text { encephalitis }\end{array}$ & (20) \\
\hline \multicolumn{4}{|l|}{ Filoviruses } \\
\hline Ebola virus* & WT & Ebola virus disease & (21) \\
\hline Marburg virus* & WT & Marburg virus disease & (22) \\
\hline Marburg virus & STAT2 ${ }^{-/-}$ & Marburg virus disease & (23) \\
\hline $\begin{array}{l}\text { Crimean-Congo } \\
\text { hemorrhagic fever virus }\end{array}$ & WT & $\begin{array}{l}\text { Crimean Congo } \\
\text { hemorrhagic fever }\end{array}$ & (24) \\
\hline \multicolumn{4}{|l|}{ Arenaviruses } \\
\hline Pichinde virus & WT & Lassa fever-like & (25) \\
\hline Pirital virus & WT & Arenavirus disease & (26) \\
\hline \multicolumn{4}{|l|}{ Phleboviruses } \\
\hline Rift Valley fever virus & WT & Rift Valley fever & (27) \\
\hline Heartland virus & STAT2 $^{-/-}$ & HRTV disease & (28) \\
\hline Punta Toro virus & WT & Rift Valley fever-like* & (29) \\
\hline Gabek forest virus & WT & Rift Valley fever-like* & (30) \\
\hline $\begin{array}{l}\text { Severe fever with } \\
\text { thrombocytopenia } \\
\text { syndrome virus }\end{array}$ & STAT2-/- & $\begin{array}{l}\text { Severe fever with } \\
\text { thrombocytopenia } \\
\text { syndrome }\end{array}$ & (31) \\
\hline \multicolumn{4}{|l|}{ Others } \\
\hline Andes virus & WT & $\begin{array}{l}\text { Hantavirus pulmonary } \\
\text { syndrome }\end{array}$ & (32) \\
\hline Maporal virus & WT & $\begin{array}{l}\text { Hantavirus pulmonary } \\
\text { syndrome }\end{array}$ & (33) \\
\hline SARS coronavirus & WT & $\begin{array}{l}\text { severe acute respiratory } \\
\text { syndrome }^{\star \star}\end{array}$ & (34) \\
\hline Oncolytic adenoviruses & WT & Pancreatic cancer & (35) \\
\hline Adenoviruses & RAG1 ${ }^{-/-}$ & $\begin{array}{l}\text { Immunodeficiency } \\
\text { disease }\end{array}$ & (36) \\
\hline Adenoviruses & STAT2 $^{-/-}$ & $\begin{array}{l}\text { Immunodeficiency } \\
\text { disease }\end{array}$ & (8) \\
\hline Prions & WT & Scrapie disease & $(37)$ \\
\hline
\end{tabular}

*Adapted viruses used in model.

** Infection model, not disease model. WT, Wild-type.

\section{West Nile Virus}

The most intensively studied virus in Syrian hamsters is West Nile virus (WNV). WNV is a member of the genus Flavivirus (family Flaviviridae), an emerging zoonotic arbovirus widely distributed throughout the world (38). WNV is usually 
transmitted via bites on infected arthropods (mosquitos). In humans, the majority of WNV infections are asymptomatic, with only $20 \%$ of infected individuals developing symptomatic West Nile fever (WNF) (39). However, WNV is an important emerging neurotropic virus causing severe encephalitis in human posing a significant threat to global health (40). Syrian hamsters can be readily infected by mosquito bite, ingestion (oral) or needle inoculation and infected hamsters develop viremia and illness, with symptoms similar to those experienced during human infection $(41,42)$. Using this hamster model, Xiao et al. observed both histologic abnormalities and appearance of viral antigen in the brain first followed by the spinal cord, with infection eventually leading to acute central nervous system (CNS) injury (13). Infected hamsters developed neurological disease (43-46) and association of suppressed diaphragmatic electromyographs (EMGs) with infection of the medulla oblongata (47). Samuel et al. also found that inoculation of Syrian hamster with WNV resulted in paralysis of the hind limb ipsilateral but not contralateral to the injection site (48). Mateo et al. generated a model of immunosuppressed Syrian hamsters using cyclophosphamide and after infection the hamsters displayed similar clinical signs to those observed in an immunosuppressed cancer patient infected with WNV (49). By observing the pathogenesis of disease in WNV-infected immunocompromised hamsters, the animals were shown to develop chronic viremia and sustained renal infection for 8 months (50). Syrian hamsters not only display an adaptive immune response but also mount an innate immune response to WNV infection. Since the Syrian hamster has been shown to be a suitable model for $\mathrm{WNV}$ infection, it has also been used to test the efficacy of anti-WNV-neutralizing humanized monoclonal antibody, hE16 (44). Antibody immunoprophylaxis induced by delivery of recombinant antigens (WN-80E or WN-NS1) also protected Syrian hamster from WNV infection (51). Using a Syrian hamster model, Widman et al. successfully demonstrated that RepliVAX $\mathrm{WN}$, a single cycle flavivirus vaccine platform, was able to induce durable protective immunity against WNV challenge (52). These studies demonstrate Syrian hamster as an ideal model for study of the pathogenesis of WNV infection and assessing new approaches for WNV treatment and prevention.

\section{Yellow Fever Virus}

YFV is an arthropod-borne virus of the genus Flavivirus (family Flaviviridae) and has high morbidity and mortality rates in regions of sub-Saharan Africa and South America (53). It was one of the first viruses of humans to be identified, isolated, propagated in vitro and studied by genomic sequencing (54). The study of infection mechanism of YFV has historically been hindered by the lack of appropriate small animal model and non-human primate (NHP) models have typically been used. More recently, several research groups have generated animal models using Syrian hamsters that can be successfully infected with YFV (55-58). McArthur et al. reported adapted viral strains (Asibi/hamster p7) allow the reproduction of yellow fever disease in hamsters with features similar to the human disease (59). Further, studies have also shown that infection of Syrian hamster results in immune responses that correspond to those observed in infected humans, with marked increases in IFN- $\gamma$, IL-2, TNF- $\alpha$ in the spleen, kidney, and heart, but reduced levels of these seen in the liver. In addition, these studies found increased levels of IL-10 and reduced levels of TGF- $\beta$ in the liver, spleen, and heart in early and mid-stages of infection (60). Syrian hamster can be used both to study the pathogenesis of the YFV infection, and to validate antiviral drugs and antiviral therapies. Recent findings have shown that treatment with the anti-viral compounds $2^{\prime}$-C-methyl cytidine (61), T-1106 (62), IFN alfacon-1 (63), and BCX4430 (64) pre- and post-YFV exposure can significantly improve Syrian hamster survival. In a study by Julander et al. immunization with DEF201, an AdV type-5 vector expressing IFN alpha (IFN- $\alpha$ ), can effectively reduce the viral titer in hamster's liver and serum post-YFV infection (65). Immunoprophylaxis with XRX-001, a vaccine containing inactivated yellow fever antigen with an alum adjuvant, can elicit high titers of neutralizing antibodies in vivo to protect Syrian hamsters from YFV infection $(66,67)$. Interestingly, Xiao et al. (67) and Tesh et al. (68) demonstrate that prior exposure of Syrian hamsters to heterologous flaviviruses reduces the risk of YFV infection.

\section{Nipah Virus}

Nipah is paramyxovirus of the genus Henipavirus (family Paramyxoviridae) with a high fatality rate (69). Infection in humans usually causes severe encephalitic and respiratory disease (70). After inoculation with Nipah virus (NiV), Syrian hamsters also develop characterisitic neurological disease (12). Similar to symptoms after human infection, pathological lesions are the most severe and extensive in the hamster brain and viral antigen and RNA can be detected in neurons (11), lung (71), kidney, and spleen (11). The Syrian hamsters in the majority of $\mathrm{NiV}$ infection studies are treated by intraperitoneal (IP) injection or intranasal (IN.) delivery and these models have revealed that different inoculation method can cause diverse pathological responses (11). In Wong's work, IP injection of NiV in Syrian hamsters caused primarily neurological disease, while IN delivery developed neurological symptoms as well as labored breathing due to lung infection in the final stages of disease (11). Disease progression is usually much rapid and the time to death post-infection is shorter following intraperitoneal rather than intranasal inoculation (72). Since the Syrian hamster has shown suitability for studying NiV infection, it was further used to study the viral transmission (73-75), demonstrating that Nipah virus is transmitted efficiently via direct contact and inefficiently via fomites, but not via aerosols. Regarding the use of these models for development of disease treatment and prophylaxis, recent studies have shown that pretreatment with $\operatorname{Poly}(\mathrm{I})$-poly $\left(\mathrm{C}_{12} \mathrm{U}\right)$ can significantly decrease the mortality caused by NiV infection of Syrian hamster (76). In addition, the model was used as a platform for evaluation of vaccines for NiV (77-80). Walpita et al. discovered purified NiV-like particles (VLP) can protect the Syrian hamster using either multiple-dose or single-dose vaccination regimens followed by $\mathrm{NiV}$ challenge (81).

\section{Ebola Virus}

Ebola virus (EBOV) is one of five known viruses within the genus Ebolavirus (family Filoviridae) (10). It's classified as biosafety 
level 4 (BSL-4) pathogen by the WHO. Not only can Syrian hamsters be effectively infected with mouse adapted (MA)EBOV, they additionally display major hallmarks infection and pathogenesis seen in humans and non-human primates (NHPs). Syrian hamsters could be inoculated via intraperitoneal injection with mouse adapted Zaire Ebola virus (MA-ZEBOV). The pathology caused by this infection is similar to that of humans, which includes significant spleen and liver damage, cytokine dysregulation, severe coagulopathy, lymphocyte apoptosis, and infected organ necrosis or apoptosis $(21,82)$. The immune responses of infected Syrian hamsters include activation of $\mathrm{T}$ cell and antibody production. In a recent study, the results of Ebola virus infection in hamsters demonstrate that $\mathrm{CD} 4^{+} \mathrm{T}$ cells are required for natural immunity and CD4-dependent antibody responses are required for immunity against the virus in this model (83). Syrian hamsters can be used to evaluate a bivalent vaccine comprising recombinant Vesicular stomatitis virus (VSV) expressing two different immunogens derived from ZEBOV envelope glycoprotein (84) and Andes Virus (ANDV) (32). The results showed that a single immunization with this vaccine provides hamsters complete and sterile protection against lethal challenge with MA-ZEBOV or ANDV (85).

\section{Marburg Virus}

Marburg virus (MARV) is also a negative sense RNA virus belonging to the family Filoviridae that causes hemorrhagic fever (86). Researchers have shown that Syrian hamsters can be used to study MARV infection. The Syrian hamster model was established to study MARV infection using the Angola variant (HA-MARV) (22). In the study, hamsters inoculated with HA-MARV developed hemorrhagic manifestations, coagulation abnormalities, dysregulation of pro-inflammatory chemokines MIP-1 $\alpha$ and IP-10, and increment of type I interferon responses $(22,87)$. In addition, Atkins et al. recently developed a small animal model for wild-type MARV infection using STAT2 KO Syrian hamster, in which viral replication rapidly progresses to multiorgan infection and extensive viremia (23), demonstrating STAT2 as a key host factor affecting wild-type MARV infection.

\section{Rift Valley Fever Virus}

RVFV is a member of the Bunyaviridae family and the genus Phlebovirus $(88,89)$. RVFV is usually transmitted via bites of infected mosquitos and can lead to mild febrile illness, retinitis, fulminant hepatitis, encephalitis and viral hemorrhagic fever (90). The infection of RVFV in Syrian hamsters has been welldescribed (91). The study results have assessed the susceptibility of Syrian hamsters to RVFV infection and shown that viral infection results in viremia, elevation of viral loads in liver, brain, and spleen tissues, observation of severe hepatocellular necrosis in the early stage of infection, and intense immunoreactivity of affected hepatocytes $(27,92,93)$. Furthermore, using Syrian hamsters, Scharton et al. proved that prophylactic Favipiravir (T-705) can effectively protect infected individuals against RVFV infection and reduce delayed-onset neurologic disease observed with ribavirin treatment (94). In another study, Gowen et al. used hamsters to demonstrate protection from infection with just a single-dose intranasal treatment of the AdV-IFN $\alpha$ vector DEF201
(95). In addtion, results presented by Westover et al. demonstrate that the adenosine analog, galidesivir (BCX4430), can effectively reduce the RVFV titer in infected Syrian hamsters (96).

\section{Other Viruses}

A large number of other studies have also demonstrated that Syrian hamster is a permissive small animal model for other viruses, for example, Syrian hamster model was successfully used to test the efficacy of anti-F MAbs to reduce Hendra virus infection (12). STAT2 KO Syrian hamster have shown successful infection with Zika virus (ZIKV) and the infected hamsters displayed the similar symptoms as in human (15). Also, an immunosuppressed Syrian hamster generated by Schaecher et al. strengthened its valuable application in study of severe acute respiratory syndrome coronavirus (SARS-CoV) infection (34). Syrian hamster has successfully been characterized for infection of human influenza, including the recent H1N1, pdm09, and H3N2 viruses (97). Moreover, as a permissive immunocompetent animal model for the study of oncolytic adenovirus, its use has been expanding for the study of cancer virotherapies (98-100).

\section{SYRIAN HAMSTER USED FOR RESEARCH IN BACTERIAL AND PARASITIC INFECTIONS}

Syrian hamster is also an ideal animal model for the study of a series of human bacterial and parasite infections, and its application has been well-reported in the literature (Table 2). Among the pathogens studied, some, such as Babesiosis, Leptospirosis, and Leishmaniasis can cause fatal infection. As for studies on virus pathogenesis, the value of the Syrian hamster model is not only reflected in the study of pathological and immune response to these infections, but also in the discovery of potential drugs and treatments.

\section{Leptospira interrogan}

Pathogenic Leptospira interrogans is spirochete bacteria responsible for leptospirosis, a widespread and emerging neglected zoonotic. Syrian hamster is the preferred model to study the infection of serovars of Leptospira interrogans, with bacteria traveling rapidly to the bloodstream via the lymphatics,

TABLE 2 | Major bacterial and parasitic infection studies in the Syrian hamster.

\begin{tabular}{llll}
\hline Agent & $\begin{array}{l}\text { Syrian } \\
\text { hamster } \\
\text { strain }\end{array}$ & Disease model & References \\
\hline Clostridium difficile & WT & $\begin{array}{l}\text { Clostridium difficile } \\
\text { disease }\end{array}$ & $(101)$ \\
Leptospira & WT & $\begin{array}{l}\text { Leptospirosis } \\
\text { Helicobacter spp. } \\
\text { Helicobacter spp. }\end{array}$ & disease \\
Entamoeba histolytica & WT & $\begin{array}{l}\text { Amebic liver abscess } \\
\text { Visceral Leishmania }\end{array}$ & $(102)$ \\
Leishmania & WT & Babesiosis & $(106)$ \\
Babesia & WT & &
\end{tabular}


then invading tissues and infecting all organs prior to the death of the hamsters (108). Similar to human, the presence of Leptospira interrogans can be detected in liver and kidney, with the destruction of hepatocyte junctions that leads to jaundice, thrombotic glomerulopathy, and interstitial nephritis $(109,110)$. Infected animals develop the enhanced expression of pro-inflammatory cytokines by peripheral blood cells, such as IL-1 $\alpha$, IL-10, TNF- $\alpha$ (111). Dramatic imbalance in the cytokine production upon Leptospira infection might play an important role in the development of severe leptospirosis (112). Since the Syrian hamster has been shown to be a suitable model, it has been used to test the efficacy of vaccines against this disease. Palaniappan et al. demonstrate that the immunization of Syrian hamster with recombinant LigA (rLigA) prevents fatalities, with decreased histopathological lesions in kidney and inhibited the growth of the organisms (113). In another study, a vaccine using a conserved region of the leptospiral immunoglobulin-like B protein ( $\mathrm{LigB}, 131-645)$ and aluminum hydroxide $(\mathrm{AH})$ can significantly increase IgG and IgM levels in the hamster, protecting the animal from mortality after challenge (114).

\section{Clostridium difficile}

Clostridium difficile disease caused by Clostridium difficile infection (CDI) is one of the most common infectious diseases worldwide (115). The increasing threat of morbidity and mortality caused by the infection is mostly due to the emergence of hypervirulent strains, increased use and misuse of antibiotics (116). The use of mouse animal model has been unable to provide CDI drug discoveries, so it is necessary to find new animal models $(117,118)$. Several groups have generated Syrian hamster models for CDI, which developed many of clinical symptoms observed in infected humans (119-121). In these studies, Syrian hamsters were conditioned with a single subcutaneous injection of clindamycin to induce Clostridium difficile colitis model. Using this infection model, the efficacy of LFF571 antibiotic against Clostridium difficile was assessed (122) and the oral mixture of kefir-isolated bacteria and yeasts to prevent diarrhea and enterocolitis triggered by Clostridium difficile was tested (123).

\section{Leishmania donovani}

Visceral leishmaniasis (VL; also known as kala-azar) is the most severe form of leishmaniasis caused by Leishmania donovani and Leishmania infantum (Leishmania chagasi in the Americas) (124). The Syrian hamster is highly susceptible to infection with visceralizing Leishmania species and is considered the best experimental model to study VL as it reproduces the clinicopathological features of human disease and quite distinct from those noted in murine models of infection (125). In the majority of studies, animals were infected by the intracardial route. Infected animals demonstrate up-regulated expression of Th1-associated cytokine mRNA, such as IFN- $\gamma$, IL-2, and TNF- $\alpha$ in the spleen, but limited induction of IL-4 mRNA (126). In murine models, Leishmania is controlled through nitric oxide (NO) generation, and however in hamsters, as in humans, NO does not have a role in macrophage function. Inducible NO synthetase (iNOS) mRNA was not detected in livers or spleen of hamsters, which may explain the uncontrolled parasite replication occurring in hamsters and humans, despite the induction of a strong Th1 cytokine response (126). Not only can Syrian hamster model be used to study the pathogenesis of Leishmania donovani infection, but also to test vaccines as recent studies have shown. Kushawaha et al. used a Syrian hamster model to show that recombinant Leishmania donovani protein disulfide isomerase (rLdPDI) generated a robust cellular immune response with increased iNOS transcription and TNF$\alpha$, IFN- $\gamma$, and IL-12 levels (127). In another study by Samant et al. vaccination with DNA-encoding N-terminal domain of the PPG gene in golden hamsters yielded $80 \%$ protection against Leishmania donovani challenge with generation of Th1 type of immune response (128).

\section{Leishmania infantum}

Besides Leishmania donovani, Leishmania infantum has also been studied using the Syrian hamster model. Moreira et al. generated a model using Syrian hamsters featuring a similar human clinical picture on Leishmania infantum infection (129). The animals developed hepatosplenomegaly, severe weight loss, anemia, and leucopenia. A study found increased levels of IgG in hamsters infected with Leishmania infantum (130). Similar to humans, Syrian hamsters can develop the progressive fatal disease, with major sites of parasites replication being the liver, spleen, and bone marrow, eventually causing death of the host (131). Infection of the hamsters showed a strong humoral response against Leishmania antigens, and high antibody levels (131). Study have tested the LJM19 (Immunization with 16 DNA plasmids coding for salivary proteins of $\mathrm{Lu}$. longipalpis) protein protected hamsters against the fatal outcome of VL (132).

\section{Entamoeba histolytica}

Entamoeba histolytica is a popular protozoan parasite causing amebiasis in humans that is a major source of morbidity and mortality in the developing countries (133). Parasitic Entamoeba histolytica produces amebic colitis and an amebic liver abscess (ALA). Syrian hamster can be successfully infected with Entamoeba histolytica (104). Similar to symptoms after human infection, the main extraintestinal complication, ALA, is also found in the hamster. In the hamster, liver recruitment of neutrophils is the initial host response to Entamoeba histolytica infection (134). A study indicated that leukocytes can induce Entamoeba histolytica trophozoites to undergo cell death (135). Although an anti-parasitic drug (Metronidazole) exists, side effects of toxicity exist in patients; thus this model has been used to develop alternative therapeutic agents. One research group showed that bovine lactoferrin protected against hepatic amoebiasis in Syrian hamster model (136). Hamsters were also used to show that intraperitoneal injection of Entamoeba histolytica surface metalloprotease (EhMSP-1), an antigen vaccine, protected against the amebic liver abscesses (137). In this study, EhMSP-1 immunization stimulated a robust IgG antibody response, IgG bound to the surface of Entamoeba histolytica trophozoites and accelerated amebic lysis via activation of the classical complement cascade. The same animal model used for Entamoeba histolytica infection was used to show 
that baculovirus driving the expression of the Gal-Lectin LC3 fragment, when administeredvia intramuscular injection, increased IFN $\gamma$ and IL-4 levels in the liver to protect against ALA (138).

\section{Schistosoma haematobium}

Schistosoma haematobium (urinary blood fluke) is the etiologic agent for urogenital schistosomiasis, a source of morbidity and mortality for over 112 million people worldwide (139). Although an improved mouse model of $S$. haematobium urinary tract infection can recapitulate several aspects of human urogenital schistosomiasis (139), Syrian hamsters still show advantages compared to mouse. Syrian hamsters can be transdermally infected with Schistosoma haematobium cercariae (140, 141). A model with Schistosoma haematobium cercariae granulomatouslike immune reaction and hepatic fibrosis infection using Syrian hamsters was generated by Botelho et al. (142). Botros et al. used Syrian hamster model to analyze and test praziquantel (PZQ) treatment (143). This animal model revealed predominant CD4 ${ }^{+}$ $\mathrm{T}$ cells in the acute phase of granuloma formation in the liver [75 days post-infection (PI)], Confluent granulomata with multiple eggs in the center were observed in the liver and urinary bladder with the preponderance of $\mathrm{CD}^{+}$positive $\mathrm{T}$ cells in the liver (95 and 115 days PI). In this model, high dose PZQ was clearly curative from 75 days PI.

\section{Others}

There are many studies detailing the pathogenesis of other bacteria and parasitic infections using the Syrian hamster animal model that cannot be discussed here in detail. A Syrian hamster model to study Borrelia burgdorferi infection was established by Johnson et al. (144). After Borrelia burgodrferi infection, hamsters were utilized to study articular manifestations of Lyme borreliosis, which is similar to human (145). Syrian hamster can be successfully infected with Leishmania panamensis (146). Infected animals have upregulated expression of type II cytokines (IL-4 and IL-13), downregulation of IL-12, and up-regulation of the type II chemokine CCL17 and its receptor CCR4 in lymph node. Grogl et al. generated a model using Syrian hamsters for drug discovery for Leishmania panamesis infection (147). After Leishmania braziliensis infection, Ribeiro-Romao et al. observed large and ulcerated lesions with elevated levels of interferon- $\gamma$ and tumor necrosis factor (TNF) during the infection endpoint, which suggests that these cytokines contribute to tissue injury (148). Treatment of Leishmania amazonensis infection by intralesional administration of dimethyl carbaporphyrin ketal (CKOMe) reduced the parasite load without noticeable toxic effects in liver (149). A Syrian hamster model to study Plasmodium berghei infection (150) demonstrated induction of severe malaria in the Syrian hamster window chamber model and was used to investigate microcirculatory changes and tissue oxygenation (151). The reader is referred to the relevant publications for further information regarding the use of Syrian hamster models to investigate these infections.
TABLE 3 | List of antibodies tested in Syrian hamster.

\begin{tabular}{|c|c|c|c|}
\hline Gene & Antibody & Applications & References \\
\hline Apaf-1 & Anti-Apaf-1 antibody & WB & $(152)$ \\
\hline Bax & Anti-Bax antibody & WB, IHC & $(152)$ \\
\hline $\mathrm{Bcl}-2$ & Anti-Bcl-2 antibody & WB, IHC & $(152)$ \\
\hline Bcl-xL & Anti-Bcl-xL antibody & WB & (153) \\
\hline Caspase-2L & Anti-Caspase-2L antibody & WB & $(152)$ \\
\hline Caspase-3 & Anti-Caspase-3 antibody & WB, IHC & $(152)$ \\
\hline Caspase-6 & Anti-Caspase- 6 antibody & WB & $(152)$ \\
\hline Caspase-8 & Anti-Caspase-8 antibody & WB & $(152)$ \\
\hline Caspase-9 & Anti-Caspase-9 antibody & WB & $(152)$ \\
\hline Cathepsin D & Anti-Cathepsin D antibody & WB, IHC & $(154)$ \\
\hline CD3 & $\begin{array}{l}\text { Anti-mouse or Syrian } \\
\text { hamster CD3 (4F11) } \\
\text { antibody }\end{array}$ & $\begin{array}{l}\text { IHC, } \\
\text { Flow Cyt }\end{array}$ & $(155,156)$ \\
\hline CD4 & $\begin{array}{l}\text { Anti-mouse CD4 (GK1.5) } \\
\text { antibody }\end{array}$ & $\begin{array}{l}\text { IHC, } \\
\text { Flow Cyt }\end{array}$ & $(157,158)$ \\
\hline $\mathrm{CD} 8 \beta$ & $\begin{array}{l}\text { Anti-rat CD8b (341) } \\
\text { antibody }\end{array}$ & Flow Cyt & $(158,159)$ \\
\hline CD20 & Anti-CD20 antibody & $\mathrm{IHC}$ & (23) \\
\hline CD25 & Anti-CD25 antibody & Flow Cyt & $(160)$ \\
\hline CD68 & Anti-CD68 antibody & $\mathrm{IHC}$ & $(161)$ \\
\hline COX-2 & Anti-COX-2 antibody & WB, IHC & $(162)$ \\
\hline $\begin{array}{l}\text { Cytochrome } \\
\text { C }\end{array}$ & $\begin{array}{l}\text { Anti-Cytochrome C } \\
\text { antibody }\end{array}$ & WB & (152) \\
\hline Fas & Anti-Fas antibody & WB & $(152)$ \\
\hline $\mathrm{IL}-4$ & Anti-IL-4 antibody & Flow Cyt & $(160)$ \\
\hline $\mathrm{IFN}-\gamma$ & Anti-IFN- $\gamma$-antibody & Flow Cyt & $(160)$ \\
\hline iNOS & Anti-iNOS antibody & $\mathrm{IHC}$ & (153) \\
\hline ICAM-1 & Anti-ICAM-1 antibody & WB & (163) \\
\hline ІкB & Anti-IאB antibody & WB & $(152)$ \\
\hline iNOS & Anti-iNOS antibody & WB & (153) \\
\hline JAK2 & Anti-JAK2 antibody & WB & (153) \\
\hline lba-1 & Anti-Iba-1 antibody & $\mathrm{IHC}$ & (159) \\
\hline MARCO & $\begin{array}{l}\text { Anti-hamster MARCO } \\
\text { (PAL-1) antibody }\end{array}$ & $\begin{array}{l}\text { IHC, } \\
\text { Flow Cyt }\end{array}$ & $(164)$ \\
\hline Mcl-1 & Anti-Mcl-1 antibody & WB & $(165)$ \\
\hline $\mathrm{MHC} \|$ & $\begin{array}{l}\text { Anti-mouse I-Ek MHC II } \\
\text { (14-4-4S) antibody }\end{array}$ & Flow Cyt & (166) \\
\hline MMP & Anti-MMP antibody & WB & (154) \\
\hline MMP-2 & Anti-MMP-2 antibody & WB, $I \mathrm{HC}$ & $(152,167)$ \\
\hline MMP-9 & Anti-MMP-9 antibody & WB & $(152)$ \\
\hline NF Kb-p50 & Anti-NF Kb-p50 antibody & WB & $(152)$ \\
\hline NF Kb-p65 & Anti-NF Kb-p65 antibody & WB & (152) \\
\hline $\mathrm{p}-\mathrm{Akt}$ & Anti-p-Akt antibody & WB & $(154)$ \\
\hline$p$-Ert & Anti-p-Ert antibody & WB & $(154)$ \\
\hline p-p65 & Anti-p-p65 antibody & WB & $(153)$ \\
\hline p-STAT3 & Anti-p-STAT3 antibody & WB, IHC & $(154,165)$ \\
\hline p21 waf-1 & Anti-p21 waf-1 antibody & WB & $(152)$ \\
\hline p53 & p53 antibody & WB, IHC & $(152,168)$ \\
\hline p65 & p65 antibody & WB, IHC & (153) \\
\hline PARP & Anti-PARP antibody & WB & $(165)$ \\
\hline Procaspase 3 & Anti-Procaspase 3 antibody & WB & (153) \\
\hline Procaspase 8 & Anti-Procaspase 8 antibody & WB & (153) \\
\hline
\end{tabular}


TABLE 3 | Continued

\begin{tabular}{llll}
\hline Gene & Antibody & Applications & References \\
\hline Procaspase 9 & Anti-Procaspase 9 antibody & WB & (153) \\
RAG1 & Anti-RAG-1(D-5) antibody & WB & WB \\
STAT2 & Anti-STAT2 antibody & WB & WB \\
STAT3 & Anti-STAT3 antibody & WB & (153) \\
Survivin (C) & Anti-Survivin (C) antibody & WB & $(165)$ \\
Survivin (N) & Anti-Survivin (N) antibody & WB & $(165)$ \\
TNF- $\alpha$ & Anti-mouse TNF $\alpha$ antibody & WB & $(154)$ \\
TRAF1 & Anti-TRAF1 antibody & WB & $(153)$ \\
Ubiqutitin & Anti-Ubiqutitin antibody & WB, IHC \\
VCAM-1 & Anti-VCAM-1 antibody & & $(161,163)$ \\
\hline
\end{tabular}

\section{CONCLUDING REMARKS}

In this review, we described the use of the Syrian hamster model as an extraordinarily effective and relevant platform for evaluation of the molecular mechanisms of immune responses to infectious diseases. These studies focus on several infectious pathogens including those of viral, parasitic, and bacterial origins. The results indicate that the Syrian hamster immune response is more physiological similar to the human immune response when compared to other animals, thus offering unique advantages when studying the disease pathogenesis and for novel drug and treatment discovery. Future studies should consider determining additional similarities between the Syrian hamster and human immune response activation through pathogen manipulation of host metabolism. Increased research efforts will ultimately allow for the development of new technologies and tools to study the Syrian hamster, such as more accurate sequencing technology along with specific antibodies against hamster

\section{REFERENCES}

1. World Health Organization (2018). Available online at: http://www.who.int/ zh/news-room/fact-sheets/detail/the-top-10-causes-of-death

2. Ogg M, Jonsson CB, Camp JV, Hooper JW. Ribavirin protects Syrian hamsters against lethal hantavirus pulmonary syndrome-after intranasal exposure to Andes virus. Viruses. (2013) 5:2704-20. doi: 10.3390/v51 12704

3. Prescott J, DeBuysscher BL, Brown KS, Feldmann H. Long-term single-dose efficacy of a vesicular stomatitis virus-based Andes virus vaccine in Syrian hamsters. Viruses. (2014) 6:516-23. doi: 10.3390/v6020516

4. Zu Rhein GM. Studies of JC virus-induced nervous system tumors in the Syrian hamster: a review. Prog Clin Biol Res. (1983) 105:205-21.

5. Cho SA, Park JH, Seok SH, Juhn JH, Kim SJ, Ji HJ, et al. Effect of granulocyte macrophage-colony stimulating factor (GM-CSF) on 5-FUinduced ulcerative mucositis in hamster buccal pouches. Exp Toxicol Pathol. (2006) 57:321-8. doi: 10.1016/j.etp.2005.09.006

6. Wang P, Li X, Wang J, Gao D, Li Y, Li H, et al. Re-designing Interleukin-12 to enhance its safety and potential as an anti-tumor immunotherapeutic agent. Nat Commun. (2017) 8:1395. doi: 10.1038/s41467-017-01385-8

7. Fan Z, Li W, Lee SR, Meng Q, Shi B, Bunch TD, et al. Efficient gene targeting in golden Syrian hamsters by the CRISPR/Cas9 system. PLoS ONE. (2014) 9:e109755. doi: 10.1371/journal.pone.0109755 proteins that are currently limited in comparison to similar tools for studying murine responses to infection. We believe that the recent advances that the Syrian hamster model has contributed enormously to our understanding of infectious diseases and disease management and demonstrates the strong potential for future research and development of anti-viral drug discovery.

However, as discussed, the lack of research tools represents a major barrier to effective use of Syrian hamster models. Immunologic reagents for examing host immune response and particular gene expression, and transgenic disease models will all be required for a more complete evaluation of the value of this model. To overcome this, research groups are developing or identifying a considerable number of antibodies against Syrian hamster (Table 3) and hamster specific quantitative real-time PCR (RT-qPCR), transcriptome analysis and microarrays have also been developed (169). Most strikingly, CRISPR/Cas9 technology has rapidly sped up the creation of transgenic Syrian hamster disease models (170). These tools will overcome the limitations to research using Syrian hamsters, opening up a powerful platform for recapitulation of human disease pathogensis.

\section{AUTHOR CONTRIBUTIONS}

JM, ZW, and YW: manuscript concept and design. JM: manuscript writing. LC, ZW, and YW: manuscript revising.

\section{FUNDING}

This project is supported by the National Key R\&D program of China (2016YFE0200800), Henan University of Chinese Medicine (Grant NO: 00104358), the National Natural Science Foundation of China (Grant NO. 81472854 to ZW) and the MRC (MR/N027655/1 and MR/M015696/1 to LC and YW).

8. Toth K, Lee SR, Ying B, Spencer JF, Tollefson AE, Sagartz JE, et al. STAT2 knockout Syrian hamsters support enhanced replication and pathogenicity of human adenovirus, revealing an important role of type I interferon response in viral control. PLoS Pathog. (2015) 11:e1005084. doi: 10.1371/journal.ppat.1005084

9. Walker DL, Padgett BL, ZuRhein GM, Albert AE, Marsh RF. Human papovavirus (JC): induction of brain tumors in hamsters. Science. (1973) 181:674-6. doi: 10.1126/science.181.41 00.674

10. Wahl-Jensen V, Bollinger L, Safronetz D, de Kok-Mercado F, Scott DP, Ebihara H. Use of the Syrian hamster as a new model of ebola virus disease and other viral hemorrhagic fevers. Viruses. (2012) 4:3754-84. doi: $10.3390 / v 4123754$

11. Wong KT, Grosjean I, Brisson C, Blanquier B, Fevre-Montange M, Bernard A, et al. A golden hamster model for human acute Nipah virus infection. Am J Pathol. (2003) 163:2127-37. doi: 10.1016/S0002-9440(10) 63569-9

12. Guillaume V, Wong KT, Looi RY, Georges-Courbot MC, Barrot L, Buckland $\mathrm{R}$, et al. Acute Hendra virus infection: analysis of the pathogenesis and passive antibody protection in the hamster model. Virology. (2009) 387:45965. doi: 10.1016/j.virol.2009.03.001

13. Xiao SY, Guzman H, Zhang H, Travassos da Rosa AP, Tesh RB. West Nile virus infection in the golden hamster (Mesocricetus auratus): a 
model for West Nile encephalitis. Emerg Infect Dis. (2001) 7:714-21. doi: 10.3201/eid0704.010420

14. McGuinness I, Beckham JD, Tyler KL, Pastula DM. An overview of yellow fever virus disease. Neurohospitalist. (2017) 7:157-8. doi: $10.1177 / 1941874417708129$

15. Siddharthan V, Van Wettere AJ, Li R, Miao J, Wang Z, Morrey JD, et al. Zika virus infection of adult and fetal STAT2 knock-out hamsters. Virology. (2017) 507:89-95. doi: 10.1016/j.virol.2017.04.013

16. Siirin MT, Duan T, Lei $H$, Guzman $H$, da Rosa AP, Watts DM, et al. Chronic St. Louis encephalitis virus infection in the golden hamster (Mesocricetus auratus). Am J Trop Med Hyg. (2007) 76:299-306. doi: 10.4269/ajtmh.2007.76.299

17. Bosco-Lauth A, Mason G, Bowen R. Pathogenesis of Japanese encephalitis virus infection in a golden hamster model and evaluation of flavivirus cross-protective immunity. Am J Trop Med Hyg. (2011) 84:727-32. doi: 10.4269/ajtmh.2011.11-0012

18. Cararra A-S, Anishchenko M, Paessler S, Aronson J, Weaver SC, Aguilar $\mathrm{P}$, et al. The hamster as an animal model for Eastern equine encephalitisand its use in studies of virus entrance into the brain. J Infect Dis. (2004) 189:2072-6. doi: 10.1086/383246

19. Jackson AC, SenGupta SK, Smith JF. Pathogenesis of Venezuelan equine encephalitis virus infection in mice and hamsters. Vet Pathol. (1991) 28:4108. doi: 10.1177/030098589102800509

20. Julander JG, Siddharthan V, Blatt LM, Schafer K, Sidwell RW, Morrey JD. Effect of exogenous interferon and an interferon inducer on western equine encephalitis virus disease in a hamster model. Virology. (2007) 360:454-60. doi: 10.1016/j.virol.2006.10.031

21. Ebihara H, Zivcec M, Gardner D, Falzarano D, LaCasse R, Rosenke R, et al. A Syrian golden hamster model recapitulating ebola hemorrhagic fever. J Infect Dis. (2013) 207:306-18. doi: 10.1093/infdis/jis626

22. Marzi A, Banadyga L, Haddock E, Thomas T, Shen K, Horne EJ, et al. A hamster model for Marburg virus infection accurately recapitulates Marburg hemorrhagic fever. Sci Rep. (2016) 6:39214. doi: 10.1038/srep 39214

23. Atkins C, Miao J, Kalveram B, Juelich T, Smith JK, Perez D, et al. Natural history and pathogenesis of wild-type Marburg virus infection in STAT2 knockout hamsters. J Infect Dis. (2018) 218:S438-47. doi: 10.1093/infdis/jiy457

24. Shepherd AJ, Leman PA, Swanepoel R. Viremia and antibody response of small African and laboratory animals to Crimean-Congo hemorrhagic fever virus infection. Am J Trop Med Hyg. (1989) 40:541-7. doi: $10.4269 /$ ajtmh.1989.40.541

25. Smee DF, Gilbert J, Leonhardt JA, Barnett BB, Huggins JH, Sidwell RW. Treatment of lethal Pichinde virus infections in weanling LVG/Lak hamsters with ribavirin, ribamidine, selenazofurin, and ampligen. Antiviral Res. (1993) 20:57-70. doi: 10.1016/0166-3542(93) 90059-R

26. Campbell CL, Phillips AT, Rico A, McGuire A, Aboellail TA, Quackenbush $\mathrm{S}$, et al. Involvement of pro-inflammatory macrophages in liver pathology of Pirital virus-infected Syrian hamsters. Viruses. (2018) 10:E232. doi: $10.3390 / \mathrm{v} 10050232$

27. Niklasson BS, Meadors GF, Peters CJ. Active and passive immunization against Rift Valley fever virus infection in Syrian hamsters. Acta Pathol Microbiol Immunol Scand C. (1984) 92:197-200. doi: 10.1111/j.1699-0463.1984.tb00074.x

28. Westover JB, Rigas JD, Van Wettere AJ, Li R, Hickerson BT, Jung KH, et al. Heartland virus infection in hamsters deficient in type I interferon signaling: protracted disease course ameliorated by favipiravir. Virology. (2017) 511:175-83. doi: 10.1016/j.virol.2017.08.004

29. Anderson GW Jr., Slayter MV, Hall W, Peters CJ. Pathogenesis of a phleboviral infection (Punta Toro virus) in golden Syrian hamsters. Arch Virol. (1990) 114:203-12. doi: 10.1007/BF01310749

30. Tesh RB, Duboise SM. Viremia and immune response with sequential phlebovirus infections. Am J Trop Med Hyg. (1987) 36:662-8. doi: 10.4269/ajtmh.1987.36.662

31. Gowen BB, Westover JB, Miao J, Van Wettere AJ, Rigas JD, Hickerson BT, et al. Modeling severe fever with thrombocytopenia syndrome virus infection in golden Syrian hamsters: importance of STAT2 in preventing disease and effective treatment with favipiravir. J Virol. (2017) 91:e01942-16. doi: 10.1128/JVI.01942-16

32. Hooper JW, Larsen T, Custer DM, Schmaljohn CS. A lethal disease model for hantavirus pulmonary syndrome. Virology. (2001) 289:6-14. doi: 10.1006/viro.2001.1133

33. Milazzo ML, Eyzaguirre EJ, Molina CP, Fulhorst CF. Maporal viral infection in the Syrian golden hamster: a model of hantavirus pulmonary syndrome. $J$ Infect Dis. (2002) 186:1390-5. doi: 10.1086/344735

34. Schaecher SR, Stabenow J, Oberle C, Schriewer J, Buller RM, Sagartz JE, et al. An immunosuppressed Syrian golden hamster model for SARS-CoV infection. Virology. (2008) 380:312-21. doi: 10.1016/j.virol.2008.07.026

35. Spencer JF, Sagartz JE, Wold WS, Toth K. New pancreatic carcinoma model for studying oncolytic adenoviruses in the permissive Syrian hamster. Cancer Gene Ther. (2009) 16:912-22. doi: 10.1038/cgt.2009.36

36. Miao J, Ying B, Li R, Tollefson AE, Spencer JF, Wold WSM, et al. Characterization of an $\mathrm{N}$-terminal non-core domain of RAG1 gene disrupted Syrian hamster model generated by CRISPR Cas9. Viruses. (2018) 10:243. doi: $10.3390 / \mathrm{v} 10050243$

37. Horiuchi M, Priola SA, Chabry J, Caughey B. Interactions between heterologous forms of prion protein: binding, inhibition of conversion, and species barriers. Proc Natl Acad Sci USA. (2000) 97:5836-41. doi: $10.1073 /$ pnas. 110523897

38. Perez-Ramirez E, Llorente F, Jimenez-Clavero MA. Experimental infections of wild birds with West Nile virus. Viruses. (2014) 6:752-81. doi: $10.3390 / \mathrm{v} 6020752$

39. Sejvar JJ. West Nile virus infection. Microbiol Spectr. (2016) 4:1-19. doi: 10.1128/microbiolspec.EI10-0021-2016

40. Suen WW, Prow NA, Hall RA, Bielefeldt-Ohmann H. Mechanism of West Nile virus neuroinvasion: a critical appraisal. Viruses. (2014) 6:2796-825. doi: $10.3390 / \mathrm{v} 6072796$

41. Komar N. West Nile viral encephalitis. Rev Sci Tech. (2000) 19:166-76. doi: 10.20506/rst.19.1.1201

42. Sbrana E, Tonry JH, Xiao SY, da Rosa AP, Higgs S, Tesh RB. Oral transmission of West Nile virus in a hamster model. Am J Trop Med Hyg. (2005) 72:325-9. doi: 10.4269/ajtmh.2005.72.325

43. Morrey JD, Day CW, Julander JG, Olsen AL, Sidwell RW, Cheney CD, et al. Modeling hamsters for evaluating West Nile virus therapies. Antiviral Res. (2004) 63:41-50. doi: 10.1016/j.antiviral.2004.02.005

44. Morrey JD, Siddharthan V, Olsen AL, Wang H, Julander JG, Hall JO, et al. Defining limits of treatment with humanized neutralizing monoclonal antibody for West Nile virus neurological infection in a hamster model. Antimicrob Agents Chemother. (2007) 51:2396-402. doi: 10.1128/AAC.00147-07

45. Morrey JD, Siddharthan V, Wang H, Hall JO, Skirpstunas RT, Olsen AL, et al. West Nile virus-induced acute flaccid paralysis is prevented by monoclonal antibody treatment when administered after infection of spinal cord neurons. J Neurovirol. (2008) 14:152-63. doi: 10.1080/13550280801958930

46. Siddharthan V, Wang H, Motter NE, Hall JO, Skinner RD, Skirpstunas RT, et al. Persistent West Nile virus associated with a neurological sequela in hamsters identified by motor unit number estimation. J Virol. (2009) 83:4251-61. doi: 10.1128/JVI.00017-09

47. Morrey JD, Siddharthan V, Wang H, Hall JO, Motter NE, Skinner $\mathrm{RD}$, et al. Neurological suppression of diaphragm electromyographs in hamsters infected with West Nile virus. J Neurovirol. (2010) 16:318-29. doi: 10.3109/13550284.2010.501847

48. Samuel MA, Wang H, Siddharthan V, Morrey JD, Diamond MS. Axonal transport mediates West Nile virus entry into the central nervous system and induces acute flaccid paralysis. Proc Natl Acad Sci USA. (2007) 104:17140-5. doi: 10.1073/pnas.0705837104

49. Mateo R, Xiao SY, Guzman H, Lei H, Da Rosa AP, Tesh RB. Effects of immunosuppression on West Nile virus infection in hamsters. Am J Trop Med Hyg. (2006) 75:356-62. doi: 10.4269/ajtmh.2006.75.356

50. Tesh RB, Siirin M, Guzman H, Travassos da Rosa AP, Wu X, Duan T, et al. Persistent West Nile virus infection in the golden hamster: studies on its mechanism and possible implications for other flavivirus infections. J Infect Dis. (2005) 192:287-95. doi: 10.1086/431153

51. Siirin MT, Travassos da Rosa AP, Newman P, Weeks-Levy C, Coller BA, Xiao SY, et al. Evaluation of the efficacy of a recombinant subunit West Nile 
vaccine in Syrian golden hamsters Am J Trop Med Hyg. (2008) 79:955-62. doi: 10.4269/ajtmh.2008.79.955

52. Widman DG, Ishikawa T, Winkelmann ER, Infante E, Bourne N, Mason PW. RepliVAX WN, a single-cycle flavivirus vaccine to prevent West Nile disease, elicits durable protective immunity in hamsters. Vaccine. (2009) 27:5550-3. doi: 10.1016/j.vaccine.2009.07.016

53. Tomori O. Yellow fever: the recurring plague. Crit Rev Clin Lab Sci. (2004) 41:391-427. doi: 10.1080/10408360490497474

54. Klitting R, Roth L, Rey FA, de Lamballerie X. Molecular determinants of yellow fever virus pathogenicity in Syrian golden hamsters: one mutation away from virulence. Emerg Microbes Infect. (2018) 7:51. doi: 10.1038/s41426-018-0053-x

55. Julander JG. Animal models of yellow fever and their application in clinical research. Curr Opin Virol. (2016) 18:64-9. doi: 10.1016/j.coviro.2016.03.010

56. Sbrana E, Xiao SY, Popov VL, Newman PC, Tesh RB. Experimental yellow fever virus infection in the golden hamster (Mesocricetus auratus) III. Clinical laboratory values. Am J Trop Med Hyg. (2006) 74:1084-9. doi: $10.4269 /$ ajtmh.2006.74.1084

57. Tesh RB, Guzman H, da Rosa AP, Vasconcelos PF, Dias LB, Bunnell JE, et al. Experimental yellow fever virus infection in the golden hamster (Mesocricetus auratus). I. Virologic, biochemical, and immunologic studies. J Infect Dis. (2001) 183:1431-6. doi: 10.1086/320199

58. Xiao SY, Zhang H, Guzman H, Tesh RB. Experimental yellow fever virus infection in the golden hamster (Mesocricetus auratus). II. Pathology. J Infect Dis. (2001) 183:1437-44. doi: 10.1086/320200

59. McArthur MA, Suderman MT, Mutebi JP, Xiao SY, Barrett AD. Molecular characterization of a hamster viscerotropic strain of yellow fever virus. J Virol. (2003) 77:1462-8. doi: 10.1128/JVI.77.2.1462-1468. 2003

60. Li G, Duan T, Wu X, Tesh RB, Soong L, Xiao S-Y. Yellow fever virus infection in Syrian golden hamsters: relationship between cytokine expression and pathologic changes. Int J Clin Exp Pathol. (2008) 1:169-79.

61. Julander JG, Jha AK, Choi JA, Jung KH, Smee DF, Morrey JD, et al. Efficacy of 2'-C-methylcytidine against yellow fever virus in cell culture and in a hamster model. Antiviral Res. (2010) 86:261-7. doi: 10.1016/j.antiviral.2010.03.004

62. Julander JG, Furuta Y, Shafer K, Sidwell RW. Activity of T-1106 in a hamster model of yellow fever virus infection. Antimicrob Agents Chemother. (2007) 51:1962-6. doi: 10.1128/AAC.01494-06

63. Julander JG, Morrey JD, Blatt LM, Shafer K, Sidwell RW. Comparison of the inhibitory effects of interferon alfacon-1 and ribavirin on yellow fever virus infection in a hamster model. Antiviral Res. (2007) 73:140-6. doi: 10.1016/j.antiviral.2006.08.008

64. Julander JG, Bantia S, Taubenheim BR, Minning DM, Kotian P, Morrey JD, et al. BCX4430, a novel nucleoside analog, effectively treats yellow fever in a hamster model. Antimicrob Agents Chemother. (2014) 58:6607-14. doi: 10.1128/AAC.03368-14

65. Julander JG, Ennis J, Turner J, Morrey JD. Treatment of yellow fever virus with an adenovirus-vectored interferon, DEF201, in a hamster model. Antimicrob Agents Chemother. (2011) 55:2067-73. doi: 10.1128/AAC.01635-10

66. Julander JG, Trent DW, Monath TP. Immune correlates of protection against yellow fever determined by passive immunization and challenge in the hamster model. Vaccine. (2011) 29:6008-16. doi: 10.1016/j.vaccine.2011.06.034

67. Xiao SY, Guzman H, da Rosa AP, Zhu HB, Tesh RB. Alteration of clinical outcome and histopathology of yellow fever virus infection in a hamster model by previous infection with heterologous flaviviruses. Am J Trop Med Hyg. (2003) 68:695-703. doi: 10.4269/ajtmh.2003.68.695

68. Tesh RB, Travassos da Rosa AP, Guzman H, Araujo TP, Xiao SY. Immunization with heterologous flaviviruses protective against fatal West Nile encephalitis. Emerg Infect Dis. (2002) 8:245-51. doi: 10.3201/eid0803.010238

69. Baseler L, de Wit E, Scott DP, Munster VJ, Feldmann H. Syrian hamsters (Mesocricetus auratus) oronasally inoculated with a Nipah virus isolate from Bangladesh or Malaysia develop similar respiratory tract lesions. Vet Pathol. (2015) 52:38-45. doi: 10.1177/0300985814556189
70. Chua KB, Bellini WJ, Rota PA, Harcourt BH, Tamin A, Lam SK, et al. Nipah virus: a recently emergent deadly paramyxovirus. Science. (2000) 288:1432-5. doi: 10.1126/science.288.5470.1432

71. Baseler L, Scott DP, Saturday G, Horne E, Rosenke R, Thomas T, et al. Identifying early target cells of Nipah virus infection in syrian hamsters. PLoS Negl Trop Dis. (2016) 10:e0005120. doi: 10.1371/journal.pntd.0005120

72. DeBuysscher BL, de Wit E, Munster VJ, Scott D, Feldmann H, Prescott J. Comparison of the pathogenicity of Nipah virus isolates from Bangladesh and Malaysia in the Syrian hamster. PLoS Negl Trop Dis. (2013) 7:e2024. doi: 10.1371/journal.pntd.0002024

73. de Wit E, Bushmaker T, Scott D, Feldmann H, Munster VJ. Nipah virus transmission in a hamster model. PLoS Negl Trop Dis. (2011) 5:e1432. doi: 10.1371/journal.pntd.0001432

74. de Wit E, Munster VJ. Animal models of disease shed light on Nipah virus pathogenesis and transmission. J Pathol. (2015) 235:196-205. doi: $10.1002 /$ path.4444

75. Luby SP, Rahman M, Hossain MJ, Blum LS, Husain MM, Gurley E, et al. Foodborne transmission of Nipah virus, Bangladesh. Emerg Infect Dis. (2006) 12:1888-94. doi: 10.3201/eid1212.060732

76. Georges-Courbot MC, Contamin H, Faure C, Loth P, Baize S, Leyssen P, et al. Poly(I)-poly(C12U) but not ribavirin prevents death in a hamster model of Nipah virus infection. Antimicrob Agents Chemother. (2006) 50:1768-72. doi: 10.1128/AAC.50.5.1768-1772.2006

77. DeBuysscher BL, Scott D, Marzi A, Prescott J, Feldmann H. Single-dose live-attenuated Nipah virus vaccines confer complete protection by eliciting antibodies directed against surface glycoproteins. Vaccine. (2014) 32:263744. doi: 10.1016/j.vaccine.2014.02.087

78. Guillaume V, Contamin H, Loth P, Georges-Courbot MC, Lefeuvre A, Marianneau P, et al. Nipah virus: vaccination and passive protection studies in a hamster model. J Virol. (2004) 78:834-40. doi: 10.1128/JVI.78.2.834-840.2004

79. Guillaume V, Contamin H, Loth P, Grosjean I, Courbot MC, Deubel V, et al. Antibody prophylaxis and therapy against Nipah virus infection in hamsters. J Virol. (2006) 80:1972-8. doi: 10.1128/JVI.80.4.1972-1978.2006

80. Lo MK, Bird BH, Chattopadhyay A, Drew CP, Martin BE, Coleman JD, et al. Single-dose replication-defective VSV-based Nipah virus vaccines provide protection from lethal challenge in Syrian hamsters. Antiviral Res. (2014) 101:26-9. doi: 10.1016/j.antiviral.2013.10.012

81. Walpita P, Cong Y, Jahrling PB, Rojas O, Postnikova E, Yu S, et al. A VLPbased vaccine provides complete protection against Nipah virus challenge following multiple-dose or single-dose vaccination schedules in a hamster model. NPJ Vaccines. (2017) 2:21. doi: 10.1038/s41541-017-0023-7

82. St. Claire MC, Ragland DR, Bollinger L, Jahrling PB. Animal models of Ebolavirus infection. Comp Med. (2017) 67:253-62.

83. Prescott J, Falzarano D, Feldmann H. Natural immunity to Ebola virus in the Syrian hamster requires antibody responses. J Infect Dis. (2015) 212(Suppl. 2):S271-6. doi: 10.1093/infdis/jiv203

84. Heppner DG Jr., Kemp TL, Martin BK, Ramsey WJ, Nichols R, Dasen EJ, et al. Safety and immunogenicity of the rVSVG-ZEBOV-GP Ebola virus vaccine candidate in healthy adults: a phase $1 \mathrm{~b}$ randomised, multicentre, double-blind, placebo-controlled, dose-response study. Lancet Infect Dis. (2017) 17:854-66. doi: 10.1016/S1473-3099(17)30313-4

85. Tsuda Y, Safronetz D, Brown K, LaCasse R, Marzi A, Ebihara H, et al. Protective efficacy of a bivalent recombinant vesicular stomatitis virus vaccine in the Syrian hamster model of lethal Ebola virus infection. J Infect Dis. (2011) 204(Suppl. 3):S1090-7. doi: 10.1093/infdis/jir379

86. Siragam V, Wong G, Qiu XG. Animal models for filovirus infections. Zool Res. (2018) 39:15-24. doi: 10.24272/j.issn.2095-8137.2017.053

87. Nakayama E, Saijo M. Animal models for Ebola and Marburg virus infections. Front Microbiol. (2013) 4:267. doi: 10.3389/fmicb.2013.00267

88. Himeidan YE, Kweka EJ, Mahgoub MM, El Rayah el A, Ouma JO. Recent outbreaks of rift valley fever in East Africa and the middle East. Front Public Health. (2014) 2:169. doi: 10.3389/fpubh.2014.00169

89. Wuerth JD, Weber F. Phleboviruses and the type I interferon response. Viruses. (2016) 8:E174. doi: 10.3390/v8060174

90. Ikegami T, Makino S. The pathogenesis of Rift Valley fever. Viruses. (2011) 3:493-519. doi: 10.3390/v3050493 
91. Turell MJ, Gargan TP II, Bailey CL. Replication and dissemination of Rift Valley fever virus in Culex pipiens. Am J Trop Med Hyg. (1984) 33:176-81. doi: 10.4269/ajtmh.1984.33.176

92. Rossi CA, Turell MJ. Characterization of attenuated strains of Rift Valley fever virus. J Gen Virol. (1988) 69(Pt 4):817-23. doi: 10.1099/0022-1317-69-4-817

93. Scharton D, Van Wettere AJ, Bailey KW, Vest Z, Westover JB, Siddharthan V, et al. Rift Valley fever virus infection in golden Syrian hamsters. PLoS ONE. (2015) 10:e0116722. doi: 10.1371/journal.pone.0116722

94. Scharton D, Bailey KW, Vest Z, Westover JB, Kumaki Y, Van Wettere A, et al. Favipiravir (T-705) protects against peracute Rift Valley fever virus infection and reduces delayed-onset neurologic disease observed with ribavirin treatment. Antiviral Res. (2014) 104:84-92. doi: 10.1016/j.antiviral.2014.01.016

95. Gowen BB, Ennis J, Bailey KW, Vest Z, Scharton D, Sefing EJ, et al. Singledose intranasal treatment with DEF201 (adenovirus vectored consensus interferon) prevents lethal disease due to Rift Valley fever virus challenge. Viruses. (2014) 6:1410-23. doi: 10.3390/v6031410

96. Westover JB, Mathis A, Taylor R, Wandersee L, Bailey KW, Sefing EJ, et al. Galidesivir limits Rift Valley fever virus infection and disease in Syrian golden hamsters. Antiviral Res. (2018) 156:38-45. doi: 10.1016/j.antiviral.2018.05.013

97. Iwatsuki-Horimoto K, Nakajima N, Ichiko Y, Sakai-Tagawa Y, Noda $\mathrm{T}$, Hasegawa $\mathrm{H}$, et al. Syrian hamster as an animal model for the study of human influenza virus infection. J Virol. (2018) 92:e01693-17. doi: 10.1128/JVI.01693-17

98. Li X, Wang P, Li H, Du X, Liu M, Huang Q, et al. The efficacy of oncolytic adenovirus is mediated by $\mathrm{T}$-cell responses against virus and tumor in Syrian hamster model. Clinc Cancer Res. (2017) 23:239. doi: 10.1158/1078-0432.CCR-16-0477

99. Toth K, Wold WS. Increasing the efficacy of oncolytic adenovirus vectors. Viruses. (2010) 2:1844-66. doi: 10.3390/v2091844

100. Wold WSM, Toth K. Syrian hamster as an animal model to study oncolytic adenoviruses and to evaluate the efficacy of antiviral compounds. In: Curiel DT, Fisher PB, editors. Advances in Cancer Research. San Diego, CA: Academic Press (2012). p. 69-92.

101. Kuehne SA, Collery MM, Kelly ML, Cartman ST, Cockayne A, Minton NP. Importance of toxin A, toxin B, and CDT in virulence of an epidemic Clostridium difficile strain. J Infect Dis. (2014) 209:83-6. doi: 10.1093/infdis/jit426

102. Haake DA. Hamster model of leptospirosis. Curr Protoc Microbiol. (2006) Chapter 12:Unit 12E 12. doi: 10.1002/9780471729259.mc12e02s02

103. Woods SE, Ek C, Shen Z, Feng Y, Ge Z, Muthupalani S, et al. Male Syrian hamsters experimentally infected with Helicobacter spp. of the H. bilis cluster develop MALT-associated gastrointestinal lymphomas. Helicobacter. (2016) 21:201-17. doi: 10.1111/hel.12265

104. Guzman-Silva MA, Santos HL, Peralta RS, Peralta JM, de Macedo HW. Experimental amoebic liver abscess in hamsters caused by trophozoites of a Brazilian strain of Entamoeba dispar. Exp Parasitol. (2013) 134:39-47. doi: 10.1016/j.exppara.2013.01.015

105. Capin R, Capin NR, Carmona M, Ortiz-Ortiz L. Effect of complement depletion on the induction of amebic liver abscess in the hamster. Arch Invest Med. (1980) 11:173-80.

106. Wilson ME, Innes DJ, Sousa AD, Pearson RD. Early histopathology of experimental infection with Leishmania donovani in hamsters. J Parasitol. (1987) 73:55-63. doi: 10.2307/3282344

107. Braga W, Venasco J, Willard L, Moro MH. Ultrastructure of Babesia WA1 (Apicomplexa: Piroplasma) during infection of erythrocytes in a hamster model. J Parasitol. (2006) 92:1104-7. doi: 10.1645/GE-712R.1

108. Murray GL, Srikram A, Henry R, Hartskeerl RA, Sermswan RW, Adler B. Mutations affecting Leptospira interrogans lipopolysaccharide attenuate virulence. Mol Microbiol. (2010) 78:701-9. doi: 10.1111/j.1365-2958.2010.07360.x

109. Gomes-Solecki M, Santecchia I, Werts C. Animal models of leptospirosis: of mice and hamsters. Front Immunol. (2017) 8:58. doi: 10.3389/fimmu.2017.00058

110. van den Ingh TS, Hartman EG. Pathology of acute Leptospira interrogans serotype icterohaemorrhagiae infection in the Syrian hamster. Vet Microbiol. (1986) 12:367-76. doi: 10.1016/0378-1135(86) 90086-6

111. Vernel-Pauillac F, Merien F. Proinflammatory and immunomodulatory cytokine mRNA time course profiles in hamsters infected with a virulent variant of Leptospira interrogans. Infect Immun. (2006) 74:4172-9. doi: 10.1128/IAI.00447-06

112. Cagliero J, Villanueva S, Matsui M. Leptospirosis pathophysiology: into the storm of cytokines. Front Cell Infect Microbiol. (2018) 8:204. doi: 10.3389/fcimb.2018.00204

113. Palaniappan RU, McDonough SP, Divers TJ, Chen CS, Pan MJ, Matsumoto $\mathrm{M}$, et al. Immunoprotection of recombinant leptospiral immunoglobulinlike protein A against Leptospira interrogans serovar Pomona infection. Infect Immun. (2006) 74:1745-50. doi: 10.1128/IAI.74.3.1745-1750.2006

114. Conrad NL, Cruz McBride FW, Souza JD, Silveira MM, Felix S, Mendonca $\mathrm{KS}$, et al. LigB subunit vaccine confers sterile immunity against challenge in the hamster model of leptospirosis. PLoS Negl Trop Dis. (2017) 11:e0005441. doi: 10.1371/journal.pntd.0005441

115. Buckley AM, Spencer J, Maclellan LM, Candlish D, Irvine JJ, Douce GR. Susceptibility of hamsters to Clostridium difficile isolates of differing toxinotype. PLoS ONE. (2013) 8:e64121. doi: 10.1371/journal.pone.0064121

116. Lo Vecchio A, Zacur GM. Clostridium difficile infection: an update on epidemiology, risk factors, and therapeutic options. Curr Opin Gastroenterol. (2012) 28:1-9. doi: 10.1097/MOG.0b013e32834bc9a9

117. Cornely OA, Crook DW, Esposito R, Poirier A, Somero MS, Weiss K, et al. Fidaxomicin versus vancomycin for infection with Clostridium difficile in Europe, Canada, and the USA: a double-blind, noninferiority, randomised controlled trial. Lancet Infect Dis. (2012) 12:281-9. doi: 10.1016/S1473-3099(11)70374-7

118. Louie TJ, Miller MA, Mullane KM, Weiss K, Lentnek A, Golan Y, et al. Fidaxomicin versus vancomycin for Clostridium difficile infection. $N$ Engl J Med. (2011) 364:422-31. doi: 10.1056/NEJMoa0910812

119. Borriello SP, Barclay FE. Protection of hamsters against Clostridium difficile ileocaecitis by prior colonisation with non-pathogenic strains. J Med Microbiol. (1985) 19:339-50. doi: 10.1099/00222615-19-3-339

120. Buckley AM, Spencer J, Candlish D, Irvine JJ, Douce GR. Infection of hamsters with the UK Clostridium difficile ribotype 027 outbreak strain R20291. J Med Microbiol. (2011) 60:1174-80. doi: 10.1099/jmm.0.028514-0

121. Razaq N, Sambol S, Nagaro K, Zukowski W, Cheknis A, Johnson S, et al. Infection of hamsters with historical and epidemic BI types of Clostridium difficile. J Infect Dis. (2007) 196:1813-9. doi: 10.1086/523106

122. Trzasko A, Leeds JA, Praestgaard J, Lamarche MJ, McKenney D. Efficacy of LFF571 in a hamster model of Clostridium difficile infection. Antimicrob Agents Chemother. (2012) 56:4459-62. doi: 10.1128/AAC.06355-11

123. Bolla PA, Carasi P, Bolla Mde L, De Antoni GL, Serradell Mde L. Protective effect of a mixture of kefir-isolated lactic acid bacteria and yeasts in a hamster model of Clostridium difficile infection. Anaerobe. (2013) 21:28-33. doi: 10.1016/j.anaerobe.2013.03.010

124. Kumar R, Nylen S. Immunobiology of visceral leishmaniasis. Front Immunol. (2012) 3:251. doi: 10.3389/fimmu.2012.00251

125. Loria-Cervera EN, Andrade-Narvaez FJ. Animal models for the study of leishmaniasis immunology. Revista Inst Med Trop São Paulo. (2014) 56:1-11. doi: 10.1590/S0036-46652014000100001

126. Melby PC, Chandrasekar B, Zhao W, Coe JE. The hamster as a model of human visceral leishmaniasis: progressive disease and impaired generation of nitric oxide in the face of a prominent Th1-like cytokine response. $J$ Immunol. (2001) 166:1912. doi: 10.4049/jimmunol.166.3.1912

127. Kushawaha PK, Gupta R, Tripathi CD, Sundar S, Dube A. Evaluation of Leishmania donovani protein disulfide isomerase as a potential immunogenic protein/vaccine candidate against visceral leishmaniasis. PLoS ONE. (2012) 7:e35670. doi: 10.1371/journal.pone.0035670

128. Samant M, Gupta R, Kumari S, Misra P, Khare P, Kushawaha PK, et al. Immunization with the DNA-encoding N-terminal domain of proteophosphoglycan of Leishmania donovani generates Th1-type immunoprotective response against experimental visceral leishmaniasis. $J$ Immunol. (2009) 183:470-9. doi: 10.4049/jimmunol.0900265

129. Moreira N, Vitoriano-Souza J, Roatt BM, Vieira PM, Coura-Vital W, Cardoso $\mathrm{JM}$, et al. Clinical, hematological and biochemical alterations in hamster (Mesocricetus auratus) experimentally infected with Leishmania infantum 
through different routes of inoculation. Parasites Vectors. (2016) 9:181. doi: 10.1186/s13071-016-1464-y

130. DE Lima Celeste JL, Venuto Moura AP, Franca-Silva JC, Matos DE Sousa G, Oliveira Silva S, Norma Melo M, et al. Experimental mixed infection of Leishmania (Leishmania) amazonensis and Leishmania (L.) infantum in hamsters (Mesocricetus auratus). Parasitology. (2017) 144:1191-202. doi: $10.1017 /$ S0031182017000464

131. Requena JM, Soto M, Doria MD, Alonso C. Immune and clinical parameters associated with Leishmania infantum infection in the golden hamster model. Vet Immunol Immunopathol. (2000) 76:269-81. doi: 10.1016/S0165-2427(00)00221-X

132. Gomes R, Teixeira C, Teixeira MJ, Oliveira F, Menezes MJ, Silva C, et al. Immunity to a salivary protein of a sand fly vector protects against the fatal outcome of visceral leishmaniasis in a hamster model. Proc Natl Acad Sci USA. (2008) 105:7845-50. doi: 10.1073/pnas.0712153105

133. Martinez-Castillo M, Pacheco-Yepez J, Flores-Huerta N, Guzman-Tellez P, Jarillo-Luna RA, Cardenas-Jaramillo LM, et al. Flavonoids as a natural treatment against Entamoeba histolytica. Front Cell Infect Microbiol. (2018) 8:209. doi: 10.3389/fcimb.2018.00209

134. Tsutsumi V, Mena-Lopez R, Anaya-Velazquez F, Martinez-Palomo A. Cellular bases of experimental amebic liver abscess formation. Am J Pathol. (1984) 117:81-91.

135. Villalba-Magdaleno JD, Perez-Ishiwara G, Serrano-Luna J, Tsutsumi V, Shibayama M. In vivo programmed cell death of Entamoeba histolytica trophozoites in a hamster model of amoebic liver abscess. Microbiology. (2011) 157:1489-99. doi: 10.1099/mic.0.047183-0

136. Ordaz-Pichardo C, Leon-Sicairos N, Hernandez-Ramirez VI, TalamasRohana P, de la Garza M. Effect of bovine lactoferrin in a therapeutic hamster model of hepatic amoebiasis. Biochem Cell Biol. (2012) 90:425-34. doi: 10.1139/o11-084

137. Roncolato EC, Teixeira JE, Barbosa JE, Zambelli Ramalho LN, Huston CD. Immunization with the Entamoeba histolytica surface metalloprotease EhMSP-1 protects hamsters from amebic liver abscess. Infect Immun. (2015) 83:713-20. doi: 10.1128/IAI.02490-14

138. Meneses-Ruiz DM, Aguilar-Diaz H, Bobes RJ, Sampieri A, Vaca L, Laclette JP, et al. Protection against amoebic liver abscess in hamster by intramuscular immunization with an Autographa californica Baculovirus driving the expression of the Gal-Lectin LC3 fragment. BioMed Res Int. (2015) 2015:760598. doi: 10.1155/2015/760598

139. Fu CL, Odegaard JI, Herbert DR, Hsieh MH. A novel mouse model of Schistosoma haematobium egg-induced immunopathology. PLoS Pathog. (2012) 8:e1002605. doi: 10.1371/journal.ppat.1002605

140. Le TL, Boyett DM, Hurley-Novatny A, Hsieh MH. Hamster weight patterns predict the intensity and course of Schistosoma haematobium infection. $J$ Parasitol. (2015) 101:542-8. doi: 10.1645/14-600

141. Ghandour AM. The development of Schistosoma haematobium in the hamster. Ann Trop Med Parasitol. (1978) 72:219-25. doi: 10.1080/00034983.1978.11719309

142. Botelho MC, Oliveira PA, Vieira P, Delgado Mde L, Lourenco L, Lopes C, et al. Granulomatous-like immune reaction and hepatic fibrosis induced by Schistosoma haematobium immature worms. Virulence. (2010) 1:123-9. doi: $10.4161 /$ viru.1.3.11348

143. Botros SS, Hammam OA, El-Lakkany NM, El-Din SH, Ebeid FA. Schistosoma haematobium (Egyptian strain): rate of development and effect of praziquantel treatment. J Parasitol. (2008) 94:386-94. doi: $10.1645 /$ GE-1270.1

144. Johnson RC, Marek N, Kodner C. Infection of Syrian hamsters with Lyme disease spirochetes. J Clin Microbiol. (1984) 20:1099-101.

145. Munson E, Nardelli DT, Du Chateau BK, Callister SM, Schell RF. Hamster and murine models of severe destructive Lyme arthritis. Clin Dev Immunol. (2012) 2012:504215. doi: 10.1155/2012/504215

146. Espitia CM, Zhao W, Saldarriaga O, Osorio Y, Harrison LM, Cappello $M$, et al. Duplex real-time reverse transcriptase PCR to determine cytokine mRNA expression in a hamster model of New World cutaneous leishmaniasis. BMC Immunol. (2010) 11:31. doi: 10.1186/1471-2172-11-31

147. Grogl M, Hickman M, Ellis W, Hudson T, Lazo JS, Sharlow ER, et al. Drug discovery algorithm for cutaneous leishmaniasis. Am J Trop Med Hyg. (2013) 88:216-21. doi: 10.4269/ajtmh.11-0812
148. Ribeiro-Romão RP, Moreira OC, Osorio EY, Cysne-Finkelstein L, GomesSilva A, Valverde JG, et al. Comparative evaluation of lesion development, tissue damage, and cytokine expression in golden hamsters (Mesocricetus auratus) infected by inocula with different Leishmania (Viannia) braziliensis concentrations. Infect Immun. (2014) 82:5203-13. doi: 10.1128/IAI.02083-14

149. Taylor VM, Cedeno DL, Munoz DL, Jones MA, Lash TD, Young AM, et al. In vitro and in vivo studies of the utility of dimethyl and diethyl carbaporphyrin ketals in treatment of cutaneous leishmaniasis. Antimicrob Agents Chemother. (2011) 55:4755-64. doi: 10.1128/AAC.00671-11

150. Franz DR, Lee M, Seng LT, Young GD, Baze WB, Lewis GE Jr. Peripheral vascular pathophysiology of Plasmodium berghei infection: a comparative study in the cheek pouch and brain of the golden hamster. Am J Trop Med Hyg. (1987) 36:474-80. doi: 10.4269/ajtmh.1987.36.474

151. Martini J, Gramaglia I, Intaglietta M, van der Heyde HC. Impairment of functional capillary density but not oxygen delivery in the hamster window chamber during severe experimental malaria. Am J Pathol. (2007) 170:50517. doi: 10.2353 /ajpath.2007.060433

152. Nagini S, Letchoumy PV, A T, Cr R. Of humans and hamsters: a comparative evaluation of carcinogen activation, DNA damage, cell proliferation, apoptosis, invasion, and angiogenesis in oral cancer patients and hamster buccal pouch carcinomas. Oral Oncol. (2009) 45:e31-7. doi: 10.1016/j.oraloncology.2009.01.006

153. Prakobwong S, Khoontawad J, Yongvanit P, Pairojkul C, Hiraku Y, Sithithaworn P, et al. Curcumin decreases cholangiocarcinogenesis in hamsters by suppressing inflammation-mediated molecular events related to multistep carcinogenesis. Int J Cancer. (2011) 129:88-100. doi: $10.1002 /$ ijc. 25656

154. Miyata S, Takemura G, Kawase Y, Li Y, Okada H, Maruyama R, et al. Autophagic cardiomyocyte death in cardiomyopathic hamsters and its prevention by granulocyte colony-stimulating factor. Am J Pathol. (2006) 168:386-97. doi: 10.2353/ajpath.2006.050137

155. Li R, Miao J, Tabaran A-F, O'Sullivan MG, Anderson KJ, Scott PM, et al. A novel cancer syndrome caused by KCNQ1-deficiency in the golden Syrian hamster. J Carcinog. (2018) 17:6. doi: 10.4103/jcar.JCar_5_18

156. Tysome JR, Li X, Wang S, Wang P, Gao D, Du P, et al. A novel therapeutic regimen to eradicate established solid tumors with an effective induction of tumor-specific immunity. Clin Cancer Res. (2012) 18:6679-89. doi: 10.1158/1078-0432.CCR-12-0979

157. Dondji B, Bungiro RD, Harrison LM, Vermeire JJ, Bifulco C, McMahon-Pratt D, et al. Role for nitric oxide in hookworm-associated immune suppression. Infect Immun. (2008) 76:2560-7. doi: 10.1128/IAI.00094-08

158. Prescott J, Safronetz D, Haddock E, Robertson S, Scott D, Feldmann $\mathrm{H}$. The adaptive immune response does not influence hantavirus disease or persistence in the Syrian hamster. Immunology. (2013) 140:168-78. doi: $10.1111 / \mathrm{imm} .12116$

159. Hammerbeck CD, Hooper JW. T cells are not required for pathogenesis in the Syrian hamster model of hantavirus pulmonary syndrome. J Virol. (2011) 85:9929-44. doi: 10.1128/JVI.05356-11

160. Kaewraemruaen C, Sermswan RW, Wongratanacheewin S. Induction of regulatory T cells by Opisthorchis viverrini. Parasite Immunol. (2016) 38:68897. doi: 10.1111/pim.12358

161. Guo X, Gao M, Wang Y, Lin X, Yang L, Cong N, et al. LDL Receptor gene-ablated hamsters: a rodent model of familial hypercholesterolemia with dominant inheritance and diet-induced coronary atherosclerosis. EBioMedicine. (2018) 27:214-24. doi: 10.1016/j.ebiom.2017.12.013

162. Segawa E, Hashitani S, Toyohara Y, Kishimoto H, Noguchi K, Takaoka $\mathrm{K}$, et al. Inhibitory effect of sulindac on DMBA-induced hamster cheek pouch carcinogenesis and its derived cell line. Oncol Rep. (2009) 21:869-74. doi: 10.3892/or_00000296

163. Falcinelli S, Gowen BB, Trost B, Napper S, Kusalik A, Johnson $\mathrm{RF}$, et al. Characterization of the host response to pichinde virus infection in the Syrian golden hamster by species-specific kinome analysis. Mol Cell Proteomics. (2015) 14:646-57. doi: 10.1074/mcp.M114. 045443

164. Palecanda A, Paulauskis J, Al-Mutairi E, Imrich A, Qin G, Suzuki H, et al. Role of the scavenger receptor MARCO in alveolar macrophage binding of unopsonized environmental particles. J Exp Med. (1999) 189:1497-506. doi: 10.1084/jem.189.9.1497 
165. Priyadarsini RV, Vinothini G, Murugan RS, Manikandan P, Nagini S. The flavonoid quercetin modulates the hallmark capabilities of hamster buccal pouch tumors. Nutr Cancer. (2011) 63:218-26. doi: 10.1080/01635581.2011.523503

166. Liu H, Steiner BM, Alder JD, Baertschy DK, Schell RF. Immune T cells sorted by flow cytometry confer protection against infection with Treponema pallidum subsp. pertenue in hamsters. Infect Immun. (1990) 58:1685-90.

167. Chow PH, Jiang HY, Poon HK, Lee KH, O WS. Embryos sired by males without accessory sex glands induce failure of uterine support: a study of VEGF, MMP and TGF expression in the golden hamster. Anat Embryol. (2003) 206:203-13. doi: 10.1007/s00429-002-0290-5

168. Silvan S, Manoharan S. Apigenin prevents deregulation in the expression pattern of cell-proliferative, apoptotic, inflammatory and angiogenic markers during 7,12-dimethylbenz[a]anthracene-induced hamster buccal pouch carcinogenesis. Arch Oral Biol. (2013) 58:94-101. doi: 10.1016/j.archoralbio.2012.06.005

169. Warner BM, Safronetz D, Kobinger GP. Syrian hamsters as a small animal model for emerging infectious diseases: advances in immunologic methods.
In: Rezza G, Ippolito G, editors. Emerging and Re-emerging Viral Infections: Advances in Microbiology, Infectious Diseases and Public Health. Vol. 6. Cham: Springer International Publishing (2017). p. 87-101.

170. Li R, Miao J, Fan Z, Song S, Kong IK, Wang Y, et al. Production of genetically engineered golden Syrian hamsters by pronuclear injection of the CRISPR/Cas9 complex. J Vis Exp. (2018) 131:e56263. doi: 10.3791/56263

Conflict of Interest: The authors declare that the research was conducted in the absence of any commercial or financial relationships that could be construed as a potential conflict of interest.

Copyright (c) 2019 Miao, Chard, Wang and Wang. This is an open-access article distributed under the terms of the Creative Commons Attribution License (CC BY). The use, distribution or reproduction in other forums is permitted, provided the original author(s) and the copyright owner(s) are credited and that the original publication in this journal is cited, in accordance with accepted academic practice. No use, distribution or reproduction is permitted which does not comply with these terms. 